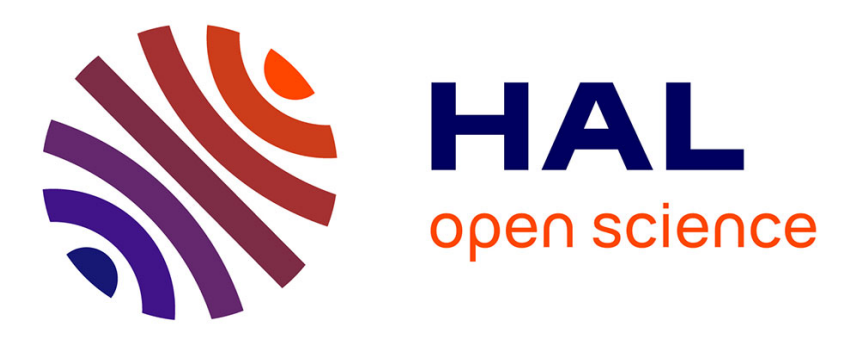

\title{
Consequences of clinical case management for caregivers a systematic review
}

\author{
Aline Corvol, Adina Dreier, Joachim Prudhomm, Jochen Rene Thyrian, \\ Wolfgang Hoffmann, Dominique Somme
}

\section{To cite this version:}

Aline Corvol, Adina Dreier, Joachim Prudhomm, Jochen Rene Thyrian, Wolfgang Hoffmann, et al.. Consequences of clinical case management for caregivers a systematic review. International Journal of Geriatric Psychiatry, 2017, 32 (5), pp.473-483. 10.1002/gps.4679 . hal-01921755

\section{HAL Id: hal-01921755 \\ https://hal-univ-rennes1.archives-ouvertes.fr/hal-01921755}

Submitted on 14 Nov 2018

HAL is a multi-disciplinary open access archive for the deposit and dissemination of scientific research documents, whether they are published or not. The documents may come from teaching and research institutions in France or abroad, or from public or private research centers.
L'archive ouverte pluridisciplinaire HAL, est destinée au dépôt et à la diffusion de documents scientifiques de niveau recherche, publiés ou non, émanant des établissements d'enseignement et de recherche français ou étrangers, des laboratoires publics ou privés. 


\section{Consequences of clinical case management for caregivers: a systematic review}

Aline Corvol, $\mathrm{MD}^{1,2,6}$, Adina Dreier, $\mathrm{PhD}^{3,4}$, Joachim Prudhomm², Jochen $\mathrm{R}$. Thyrian, $\mathrm{MD}^{3}$, Wolfgang Hoffmann, $\mathrm{MD}, \mathrm{PhD}^{3,4}$, Dominique Somme, MD, $\mathrm{PhD}^{2,5,6}$.

1. German Center for Neurodegenerative Diseases (DZNE), Bonn, Germany

2. Service de gériatrie, CHU Rennes, France

3. German Center for Neurodegenerative Diseases (DZNE), Greifswald, Germany

4. Institute for Community Medicine, Dep. Epidemiology of Health and Community Health, University Medicine, Greifswald, Germany

5. Faculté de médecine, Université de Rennes 1, France

6. Centre de Recherche sur I'Action Politique en Europe UMR 6051France.

\section{Corresponding author}

Dr Aline Corvol

acorvol@hotmail.com

CHU de Rennes

2, rue Le Guilloux

35000 Rennes

+33299284397

Fax +33299284163

Pr Dominique Somme

dominique.somme@chu-rennes.fr

CHU de Rennes

2, rue Le Guilloux

35000 Rennes

Dr Adina Dreier, Dr Jochen R. Thyrian, Pr Wolfgang Hoffmann

adina.dreier@uni-greifswald.de

rene.thyrian@dzne.de

wolfgang.Hoffmann@dzne.de;

Ellernholzstraße 1-2

17487 Greifswald

Word count : 3851

Running head : Case management and caregivers 


\section{Abstract}

Background : Informal caregivers are deeply involved in the case management process. However, little is known about the consequences of such programs for informal caregivers. This systematic literature review, reported according to the Preferred Reporting Items for Systematic Reviews and Meta-Analyses (PRISMA) Statement, addressed the consequences of clinical case management programs, whether positive or negative, for caregivers of frail elderly persons or persons with dementia.

Methods : We systematically identified and analyzed published randomized trials and quasiexperimental studies comparing case management programs to usual care which discussed outcomes concerning caregivers.

Results : Sixteen studies were identified and 12 were included after quality assessment. Seven identified at least one positive result for caregivers, and no negative effect of case management has been found. Characteristics associated with positive results for caregivers were a high intensity of case management and programs specifically addressed to dementia patients.

Conclusion : Despite the numerous methodological challenges in the assessment of such complex social interventions, our results show that case management programs can be beneficial for caregivers of dementia patients, and that positive results for patients are achieved without increasing caregivers' burden.

\section{Key words}

Systematic review, older persons, clinical case management, caregiver, persons with dementia. 


\section{Introduction}

Informal caregivers play a critical role in long-term home care and have been described as the "backbone" of the long-term care workforce (Wolff and Kasper, 2006). Because the stresses of modern society make the traditional mechanisms of providing informal care more difficult, public policy-makers have sought to find efficient ways to support caregivers (Bodsky et al., 2003). A 2002 meta-analysis (Sörensen et al., 2002), pooling a wide range of interventions with caregivers, found that appropriate interventions can lead to significant improvements in caregiver burden, level of depression, and subjective well-being, with a small to moderate effect size. Psychoeducational and psychotherapeutic interventions showed more consistent results, whereas intervention effects tended to be smaller for caregivers of dementia patients. A 2008 systematic review of literature on dementia caregivers (Parker et al.) found only weak evidence that caregivers benefit from such support. Multidisciplinary case management, as analyzed in the three trials examined by the study, seemed to decrease depression scores in caregivers, but this result was not statistically significant. Paradoxically, interventions such as respite care increased caregiver burden. A recent review (Berthelsen et al., 2015) considered effects of case management addressed to informal caregiver of older adults, both on patients and caregivers. Because of a restrictive search algorithm, with a mandatory focus on health information or shared decision making, and methodological limitations (inconsistence in the definition of case management and of caregiver), this review don't provide reliable results concerning caregivers.

However, case management, which can be defined as a "targeted, community-based and pro-active approach to care that involves case-finding, assessment, care planning, and care coordination," always involves both the patient and the caregivers (Ross et al., 2011). This is especially true considering Applebaum \& Austin (1990) definition of case management, 
characterized by three factors: intensity of involvement, breadth of services spanned, and long-term commitment.

Thus, there are two reasons to monitor consequences of case management on caregivers. First, the caregiver can be seen as a part of the caring system, and caregiver support can enhance quality of the care the patient receives. Second, personal interests of the caregiver should be taken into account. Consequences could be beneficial or detrimental, as case management may either reduce or increase caregiver burden.

In keeping with this perspective, the present review has studied the full range of consequences of case management for caregivers of frail elderly persons or persons with dementia. A systematic retrieval of randomized clinical trials and quasi-experimental studies comparing case management and usual care was conducted, in order to answer the following questions: 1) How does case management affect caregivers? 2) What aspects of the case management program could explain the variations in consequences for caregivers? 3) What patient or caregiver characteristics could explain variations in consequences for caregivers? 4) Is case management efficiency for care recipients associated with a positive or negative effect on caregivers?

\section{Methods}

The systematic review presented here was undertaken by one of the authors and was not preregistered as a protocol. This report meets the criteria of the Preferred Reporting Items for Systematic Reviews and Meta-Analysis (PRISMA) statement for systematic reviews (Moher et al., 2009) .

The present study focuses on primary caregivers of elderly patients with loss of autonomy or persons with dementia without age limit. Patients included in the retrieved studies were considered "elderly" if their average age was more than 75 years. The definition of caregiver was the one chosen by the researchers in each trial, which did not necessarily include a family link or a shared home. 
In order to make valid comparisons among the explored interventions, only studies in which "a designated care manager combines the planning and coordination with a therapeutic, supportive role" (Challis et al., 2002), under a model referred to as clinical case management (Kanter, 1989; Surber, 1994) or as intensive care management (Challis et al., 2002), were included. Only studies comparing the specified case management program approach to standard care without any form of case management were included. Quasi-experimental studies were retained because those studies can have a high external validity (Koch et al., 2012). Case management programs that provided only distance services or were limited to education were excluded, as were short term discharge intervention (i. e. transitional care) lasting less than 3 months. All relevant studies published in peer-reviewed journals were considered, regardless of publication date and language. Concerning time-limited interventions, only the outcome assessment at the end of the program was retained; post hoc studies on part of a sample were discarded.

We began our electronic search on the Scopus Database, which includes all MEDLINE articles and indexes 18,500 peer-reviewed journals, including human sciences and nonEnglish journals (http://www.info.sciverse.com/scopus/scopus-in-detail/facts). We developed our search algorithm from a first non-systematic literature review, using index mapping (Strech et al., 2008). We searched in title, abstract, and keywords for the terms "case management" or "care management" or "disease management" or "guided care" or "family intervention" or "integrated care," in association with "controlled study" or "comparative study" or "prospective experimental design," associated with "caregiver" in the text. This search, conducted in May 2016, was limited to articles, and articles indexed with "child" as a keyword were excluded. Complementary searches were performed in additional databases, that is, EMBASE, ISI Web of Knowledge, the Cochrane Central Register of Controlled Trials , PsycINFO, CSA Social Services Abstract, and FRANCIS. 
All articles were screened by title, and all abstracts of possibly relevant articles were read. Full texts of potentially relevant studies were then retrieved and checked against inclusion and exclusion criteria. Reference lists of selected articles were checked in order to identify other relevant studies. No authors were contacted.

The methodological quality of the randomized studies was systematically assessed for each outcome using the Cochrane Collaboration tool for assessing risk of bias in randomized trials (Higgins et al., 2011). This tool focuses on internal validity and suggests judging the risk of bias in five domains: selection, performance, detection, attrition, and reporting. We added a systematic examination of implementation (Boutron et al., 2008) and contamination biases, because of their relevance to the evaluation of socially complex services (Wolff et al., 2000). Results were then summarized as low, acceptable, high, or unclear.

The potential biases resulting from the absence of blinding differed according to the outcome considered. We maintained that there was a high risk of performance bias on the outcome "satisfaction with care" as caregivers who felt they had "won" the randomization process, or get the "best" service in quasi-experimental studies, might well feel more satisfied. In addition, we saw a high risk of detection bias on the outcome "declared hours of caring," especially when no in-depth research interview were undertaken, since a case manager's assessment could influence the caregiver's awareness of his/her involvement in everyday care. We considered the performance bias on the caregiver's quality of life to be acceptable, as it has been demonstrated that the Hawthorne effect (i.e., the bias linked with attention and multiple assessments), is not large enough to significantly affect quality of life for caregivers of dementia patients (Mc Carney et al., 2007) . By extension, we considered the potential performance bias linked with the absence of blinding on caregiver burden and depression, for both dementia and non-dementia patients, to be acceptable. Non-randomized studies were classified according to the same criteria, taking into account their inherent risk of selection bias. Internal validity assessment was conducted by two reviewers independently, both experienced researchers in the area of case management. Inconsistencies were 
resolved by discussion. Results of studies with low internal validity were excluded from further analysis. In included studies, outcomes with high risk of bias were not considered.

As quality cannot be reduced to internal validity, external validity was assessed as well (Verhagen et al., 2001). In keeping with Wolff's recommendation on socially complex services evaluation (Wolff et al.,2000), we defined two important domains: the representativeness of the research sample, and the accuracy of the description of the interventions, that allows replication of the intervention in similar contexts. External validity was classified as low, acceptable, high, or unclear.

In order to identify elements that might explain differences in outcomes, we systematically collected program and population characteristics. Program descriptions were analyzed in order to assess program intensity and level of integration. The simplest way to evaluate case management intensity is to consider the case manager's case load (the greater the case load, the lower the intensity) (Somme et al., 2012). To refine this approach, we also considered the frequency of home visits, the range of services (Pacala et al., 1995), and the complexity of the needs of the target population (Challis 2002). We estimated level of integration on the basis of case managers' links with primary care practice, service providers, acute-care facilities, and long-term-care facilities (Kodner, 2002). Intensity and integration were estimated as low, moderate, high, or unclear. As no consensually validated tool exists to assess external validity, case management intensity, and case management integration, these assessments were made by the two reviewers through continuous discussions to achieve agreement.

Finally, in order to identify elements that might explain differences in outcomes, we systematically collected program and population characteristics. Program descriptions were analyzed in order to assess program intensity and level of integration. Relevant characteristics of the caregiver population were determined - in particular, the proportion of women, and the proportion of spouses, since those characteristics are known to influence caregiver burden (Carretero et al., 2009). We also collected statistically significant results 
concerning patients, in order to assess the relationship between patient and caregiver outcomes.

A vote-count review was performed on caregiver outcomes, summarizing those reflecting burden (or strain or distress), satisfaction, health-related quality of life (or psychological health), depression, and social support. Sub-group analyses were carried out in terms of patient characteristics (persons with dementia versus elderly persons) and patient results, caregiver characteristics, and intensity and integration levels for case management.

\section{Results}

\section{Selection of Studies}

Our bibliographic search in Scopus identified 481 articles. The selection process (Figure 1) led us to include 16 studies (Table 1). Frequently assessed outcomes were caregiver burden (13 studies), caregiver health-related quality of life or psychological health (8 studies), caregiver depression (4 studies), satisfaction with care (3 studies), or social support (3 studies). Other outcomes considered by at least one study were caring hours, caregiver sense of competence, personal well-being, family functioning, desire to institutionalize, productivity loss and loneliness .

Eleven randomized controlled trial studies and five quasi-experimental studies were analyzed. No randomized trial was blinded for participants, which makes senses, as such blinding would be difficult, if not impossible, for case management. Assessment was blinded in 11 studies, non-blinded in 5, and unclear in one. Three of the five quasi-experimental studies were considered to have low internal validity, mostly because of significant differences between experimental and control groups at inclusion. One randomized controlled trial with only one caregiver outcome, declared hours of caring, was considered to have low internal validity for this outcome because of a detection bias. These four studies were excluded from further analysis. Reviewers agreed on conclusions concerning internal 
validity for all randomized trials, but discussions were necessary for the two quasiexperimental studies that have finally been accepted.

There were no studies with high internal validity. The 12 remaining studies were judged to have unclear (2 studies) or acceptable (10 studies) internal validity, in spite of moderate risks of performance, detection, implementation, or contamination bias. Five studies had low external validity, mainly because they lacked a systematic recruitment strategy. Table 2 summarizes the results concerning the internal and external validity of each study, and specifies the kinds of bias that could affect the results. We included two studies published by Chien and Lee $(2008,2011)$ despite some questions about these reports: they describe two very similar trials without discussion on the additional value of the second study.

\section{Outcomes for Caregivers}

Seven of the 12 studies found at least one valid positive outcome for caregivers [Table 3]. Four of the 11 studies assessing caregiver burden showed a reduction. Four of the 7 studies assessing quality of life for caregivers yielded positive results; one of 3 on caregiver social support showed positive results. The 4 studies that assessed depression in caregivers found no significant differences at the end of the intervention. Callahan (2006) found a significant result on depression score 6 months after the end of the intervention. No studies demonstrate any negative effects of case management on caregivers.

\section{Pre-specified Sub-group Analysis}

In further analyses we tried to understand which aspects of a case management program could explain variations in the program's efficacy for caregivers. As it was not possible to control for all confounding factors, especially the variability of the context, the further analyses should be regarded as exploratory. 
To analyze intensity and integration influence, we separate here two different case management models compared with control group by McNeil : the "intensive" one, and the "linkage model".

Patient profiles are important determinants of efficacy. As Table 4 shows, none of the programs aimed at elderly patients showed positive outcomes for caregivers. Selection criteria were different (table1) according to the studies, but all these, except in Leung study (2004), can be qualified of "frail", because of a loss of autonomy or a high risk of using health service resource. Six of the ten programs targeted to dementia patients found positive outcomes for caregivers, the other having both a low or moderate integration and a moderate or unclear intensity level. The two studies aimed at mild-dementia patients only demonstrated no positive outcome. Five of the six studies with a high intensity level of case management achieved positive outcomes for caregivers whereas only one of the five studies with a moderate level of intensity achieved positive outcomes for caregivers. The level of integration of a case management program, patient age, or caregiver characteristics did not seem to figure highly in program efficacy.

It is important to emphasize that these results are based only on caregiver outcomes. In terms of patient outcomes, 9 of the 12 studies reported at least one positive outcome for patients, such as delaying institutionalization, reducing hospitalization, enhancing quality of life, or reducing behavioral troubles. Some programs may yield significant effects for patients, especially frail elderly, without benefit for caregivers. Parsons' study (2012) demonstrates the possibility of benefit in the form of delayed institutionalization, which was not mediated by a reduction of caregiver burden.

\section{Discussion}

Evidence concerning socially complex services is difficult to gather (Wolff, 2000). Because of the heterogeneity of study designs, interventions, contexts, and outcomes considered, we did not attempt to pool the results in a meta-analysis. We believe that this overview obtained 
through careful individual assessment of study quality, program, and outcomes can be more informative than any summary measure obtained via global pooling of different interventions. Although some uncertainty remained, due to the impossibility of conducting blinded trials, this systematic review allows us to conclude that some case management programs aimed at dementia patients can have positive outcomes for caregivers, in terms of reduction of caregiver burden, enhanced quality of life, or greater social support, but not on depression. Caregivers of patients with mild dementia may not be the persons who benefit most from case management programs (Jansen et al., 2011). There is no evidence that case management programs may have positive outcomes for caregivers of frail elderly, but such programs can reduce hospitalization (Leung et al., 2004; Béland et al., 2006) or delay institutionalization (Parson et al., 2012) without increasing caregiver burden.

Our systematic review has several limitations. In addition to the usual publication bias, identification of all the relevant studies has proven challenging, since case management programs can be described by different terms. Despite the care we took in building a systematic search algorithm, it is possible that some relevant studies were not identified. Ultimately, however, any real weakness in this systematic review lies in the quality of the studies themselves, all of which were based on subjective outcomes which could have been biased by the absence of blinding. Another potentially important bias concerns implementation, as most of the studies reported no implementation results. Three studies attributed disappointing results to inadequate program implementation (Vickrey et al., 2006; Jansen et al., 2011; Fox et al., 2000). Contamination may also have occurred, especially in trials with individualized randomization: good practices implemented by case managers could have also benefitted the control group, if the same professionals were involved in both groups. Whereas the implementation and contamination bias may have reduced the results, the non-blinded design might have increased them.

It has proved difficult to identify aspects of case management program and patients selection associated with better results. This is mainly due to an insufficient reporting, and to the 
heterogeneity of studies. Intensity and integration levels were especially difficult to determine. When MacNeil compares with control group two different models of case management, named "intensive" and "linkage", it happens that the case load is similar in the two models (more important in the linkage model, though non significant), the intensive model referring in fact to a more integrated model, more efficient on caregiver psychological health. This stresses the necessity of a complete description of implemented interventions.

The value of quasi-experimental design in evaluation of case management programs is somewhat controversial (Koch et al., 2012; Wolff, 2000). Hébert (2000) was able to provide interesting data on the strength of an extensive (4 year) follow-up of an "actually implemented" program, and it emphasizes the time required to implement a program before assessing its efficacy. Quasi-experimental studies can avoid contamination bias, when different territories are compared, and their implementation, even when only partial, corresponds to "real-life" implementation. We believe that the performance bias linked with the absence of patient blinding could be decreased by the absence of randomization, as patients would not have felt they had won something others had not. However, the detection bias is increased by the absence of a blinding assessment, usually infeasible in such studies [8]. The main problem, as observed in four such studies (Morales-Asencio et al., 2008; Hébert et al., 2010, Janse et al., 2014, McNeil et al., 2015) is the difficulty to obtain two similar groups that could allow comparison. Despite our initial choice of including quasiexperimental study ,three of five were finally not included because of significant differences in the compared groups, added with at least one other identified bias, and for the two included trial there was initially a disagreement between the expert. Challis (2002) design, with similar group obtained by matching patient pairs, and MacNeil (2015) statistical analysis using propensity score, seems valuable ways to enhance internal validity of quasiexperimental studies. Further studies could consider cluster randomization, eventually with stepped wedge design to model the effect of time (Hemming, 2015). 
Lastly, all studies included only one caregiver per patient, with different definition and often little details provided; so the effect of case management on "second line" caregivers or according to the characteristics of caregivers (spouses versus relatives versus friends) can't be specified.

Despite these limitations, we believe we have been able to gather valuable evidence on the potential benefits for caregivers of case management. Our rigorous selection of studies, based on a clear definition of case management, allow confidence in the conclusions drawn. Positive results have been obtained in very different cultural and organizational contexts, in Asia, Europe, and America. Despite the limited external applicability of some individual studies, this review provides a good representation of different contexts overall. Of course, the literature cannot provide evidence that every case management program will work everywhere, nor that any given single model will work in every context. In contrast to drug trials, case management is an intervention that cannot be completely standardized (Wolff, 2000), and researchers studying case management have to make compromises between internal and external validity (Godwin et al., 2003). So our review can only stress the possibility of implementing efficient case management programs for caregivers, and highlight the characteristics that seem to be associated with better outcomes. Until now, such programs have been nationally implemented in very different contexts, for example in Japan (Matsuda and Yamamoto, 2001), France (Somme et al, 2009), or Québec, Canada (Vedel et al, 2011).

No study showed any effect of a program on caregiver depression. That said, the relevance of such an outcome for a case management program can be questioned: if depression is envisaged as a systemic disease, involving the mind, brain and body (Gold and Charney, 2002) such intervention could address only social, external components of depression. The choice of assessment instruments for depression can also be questioned (Snaith 1993; Roman and Callen, 2008), the scales chosen to rate caregiver burden. The construction of scales is "necessarily influenced by a variety of value judgements" (Janse 2014). Burden 
scales that focus on the negative impacts of caregiving have been criticized, because that restriction prevents researchers from assessing sources of satisfaction in caregiving (Nolan 2006). Other scales that include both negative and positive impacts of caregiving could be more relevant to assessment of the global consequences of caregiving (McKee et al., 2003). The finding that studies aimed at frail elderly can yield positive results for patients without significantly affecting caregivers is in itself valuable. As such programs involve both caregivers and patients, it seems good practice to evaluate the respective effects on both.

Five studies raise questions about possible harmful effects of case management. In the Hébert study (2010), the burden increase was significantly greater in the intervention group. One hypothesis is that patient empowerment was achieved at the expense of caregiver burden. Two studies (Leung et al., 2004; Vickrey et al., 2006) found a non-significant trend in favor of an increase of caregiving hours in the intervention group, which conflicts with Challis (2001) results. It is possible that in some contexts case managers might ask caregivers to perform new caregiving tasks. Lam (2010) found a slight negative effect at 12 months on caregivers' psychological health (our review focused on the effect at the end of the intervention at 4 months), and assumed that domestic helpers' lack of experience with dementia patients, and the cost of day care facilities, may have in fact been burdensome to some family caregivers. Finally, Janse (2014) complementary study on caregiver satisfaction demonstrates the possibility of counterproductive effect of case management due to information overload or decrease clarity on "who do what" for caregiver. These results, although a minority, emphasize the necessity of considering caregiver outcomes in all case management intervention, at least as a possible side effect.

\section{Conclusion}

Our results show reasonable evidence that clinical case management can lead to positive outcomes for caregivers of dementia patients, and that positive outcomes for frail elderly 
patients can be obtained without increasing caregiver burden. Further research is needed to determine which characteristics of a program, in addition to intensity, could support the program's efficacy, and to determine which caregivers could benefit most from those programs. Even though researchers face numerous methodological challenges in building valid trials, evidence can be strengthened via accurate description of the context, of the intervention itself, and of its actual implementation, as well as through a careful choice of trial design and outcomes.

Figure 1 : Flowchart of Selection of Studies

\section{Declarations}

- Competing interests

The authors declare that they have no competing interests.

\section{Key points}

-Informal caregivers are deeply involved in the case management process

-Case management programs can achieve positive results for caregivers, especially intensive programs addressed to persons with dementia.

-Positive results for older patients, such as delaying institutionalization and reducing hospitalization, occur without impacting caregivers' outcome. 


\section{References}

Applebaum R, Austin C. 1990. Long Term Care Case Management: Design and Evaluation. New York, Springer

Berthelsen CB, Kristensson J. 2015. The content, dissemination and effects of case management interventions for informal caregivers of older adults: a systematic review. Int $\mathrm{J}$ Nurs Stud 52[5] : 988-1002. doi: 10.1016/j.jnurstu.2015.01.006.

Béland F, Bergman H, Lebel P et al. 2006. A system of integrated care for older persons with disabilities in Canada: results from a randomized controlled trial. J. Gerontol. A Biol. Sci. Med. Sci. $200661: 367-73$.

Boutron I, Moher D, Altman DG, Schulz KF, Ravaud P. 2008. Extending the CONSORT statement to randomized trials of nonpharmacologic treatment: explanation and elaboration. Ann Intern Med 148 : 295-309.

Brodsky J, Habib J, Hirschfeld M. Key policy issues in long-term care. 2003. World Health Organization collection on long-term care. World Health Organization : Geneva.

Callahan CM, Boustani MA, Unverzagt FW, Austrom MG, Damush TM, Perkins AJ, et al. 2006. Effectiveness of collaborative care for older adults with Alzheimer disease in primary care: a randomized controlled trial. JAMA. $295: 2148-57$.

Carretero S, Garcés J, Ródenas F,Sanjosé V. 2009. The informal caregiver's burden of dependent people: theory and empirical review. Arch Gerontol Geriatr 49 : 74-79.

Challis D, Darton R, Hughes J, Stewart K, Weiner K. 2001. Intensive care-management at home: an alternative to institutional care? Age Ageing 30 : 409-13.

Challis D, von Abendorff R, Brown P, Chesterman J, Hughes J. 2002. Care management, dementia care and specialist mental health services: an evaluation. International Journal of Geriatric Psychiatry 17[4] : 315-325. doi:10.1002/gps.595

Chien WT, Lee YM. 2008. A disease management program for families of persons in Hong Kong with dementia. Psychiatr Serv. 59 : 433-436. 
Chien WT, Lee YM. Randomized controlled trial of a dementia care programme for families of home-resided older people with dementia. 2011. J Adv Nurs. 67 : 774-787.

Fox P, Newcomer R, Yordi C, Arnsberger, P. 2000. Lessons learned from the Medicare Alzheimer Disease Demonstration. Alzheimer Dis Assoc Disord. 14(2) : 87-93.

Godwin M, Ruhland L, Casson I, MacDonald S, Delva D, Birtwhistle R, et al. 2003. Pragmatic controlled clinical trials in primary care: the struggle between external and internal validity. BMC Med Res Methodol 3 : 28.

Gold PW. Depression: A Disease of the Mind, Brain, and Body. 2002. Am J Psychiatry. 159(11) : 1826. DOI: 10.1176/appi.ajp.159.11.1826

Hébert R, Raîche M, Dubois M, Gueye NR, Dubuc N, Tousignant M. 2010. Impact of PRISMA, a coordination-type integrated service delivery system for frail older people in Quebec [Canada]: A quasi-experimental study. J Gerontol B Psychol Sci Soc Sci. 65 : 107118.

Hemming K, Haines TP, Chilton PJ, Girling AJ, Lilford RJ. 2015. The stepped wedge cluster randomised trial: rationale, design, analysis, and reporting. BMJ. 350:h391. doi:

10.1136/bmj.h391.

Higgins JPT, Altman DG, Gotzsche PC, Juni P, Moher D, Oxman AD, et al. 2011. The Cochrane Collaboration's tool for assessing risk of bias in randomised trials. BMJ. 2011343 : d5928.

Janse B, Huijsman R, de Kuyper RD, Fabbricotti IN. 2014. The effects of an integrated care intervention for the frail elderly on informal caregivers: a quasi-experimental study.

BMC Geriatr. 14 : 58. doi: 10.1186/1471-2318-14-58.

Jansen APD, van Hout HPJ, Nijpels G, Rijmen F, Dröes R, Pot A, et al. 2011. Effectiveness of case management among older adults with early symptoms of dementia and their primary informal caregivers: a randomized clinical trial. Int J Nurs Stud. 48 : 933-43.

Kodner DL. 2002. The quest for integrated systems of care for frail older persons. Aging Clin Exp Res. 14 : 307-313. 
Kanter J. 1989. Clinical case management: definition, principles, components. Hosp Community Psychiatry 40 : 361-68.

Koch T, Iliffe S, Manthorpe J, Stephens B, Fox C, Robinson L, et al. 2012. The potential of case management for people with dementia: a commentary. Int J Geriatr Psychiatry 27(12) : 1305-1314. doi: 10.1002/gps.3783.

Lam LCW, Lee JSW, Chung JCC et al. 2010. A randomized controlled trial to examine the effectiveness of case management model for community dwelling older persons with mild dementia in Hong Kong. Int J Geriatr Psychiatry 25 : 395-402.

Leung AC, Liu C, Chow NW. Cos, Lau A, Woo J, Kwok TCY. 2004. Cost-Benefit Analysis of a Case Management Project for the Community-Dwelling Frail Elderly in Hong Kong. $j$ appl gerontol. 23 : 70-85.

MacCarney R, Warner J, lliffe S, van Haselen R, Griffin M, Fisher P. 2007. The Hawthorne Effect: a randomised, controlled trial. BMC Med Res Methodol. 7 : 30.

MacKee KJ, Philp I, Lamura G, Prouskas C, Oberg B, Krevers B, et al. 2003. The COPE index--a first stage assessment of negative impact, positive value and quality of support of caregiving in informal carers of older people. Aging Ment Health. 7 : 39-52.

MacNeil Vroomen J, Bosmans JE, van de Ven PM, Joling KJ, van Mierlo LD, Meiland FJ, Moll van Charante EP, van Hout HP, de Rooij SE. 2015. Community-dwelling patients with dementia and their informal caregivers with and without case management: 2-year outcomes of a pragmatic trial. J Am Med Dir Assoc.; 16(9) : 800.e1-8.

doi: 10.1016/j.jamda.2015.06.011.

Matsuda S, Yamamoto M. 2001. Long-term care insurance and integrated care for the aged in Japan. Int J Integr Care; 1(3). DOI: http://doi.org/10.5334/ijic.39

Moher D, Liberati A, Tetzlaff J, Altman DG. 2009. Preferred reporting items for systematic reviews and meta-analyses: the PRISMA statement. BMJ 339 : b2535. 
Newcomer R, Yordi C, DuNah R, Fox P, Wilkinson A. 1999. Effects of the Medicare Alzheimer's Disease Demonstration on caregiver burden and depression. Health Serv Res $34: 669-689$.

Morales-Asencio JM, Gonzalo-Jiménez E, Martin-Santos FJ, Martin-Santos FJ, MorillaHerrera JC, Celdráan-Mañas Met al. 2008. Effectiveness of a nurse-led case management home care model in Primary Health Care. A quasi-experimental, controlled, multi-centre study. BMC Health Serv Res. 8 : 193.

Nolan M, Mestheneos L, Kofahl C,Melchiorre GM, Pedich W. 2006. Issues and challenges in carer support: A consideration of the literature. In: Services for Supporting Family Carers of Elderly People in Europe: Characteristics, Coverage and Usage. Trans-European Survey Report, EUROFAMCARE Consortium (ed). Hamburg University Medical Centre of HamburgEppendorf. 15-40.

Pacala JT, Boult C., Hepburn KW,.Kane RA, Kane RL, Malone JK, et al. 1995. Case management of older adults in health maintenance organizations. J Am Geriatr Soc $\mathbf{4 3}$ : $538-542$.

Parker D, Mills S, Abbey J. 2008. Effectiveness of interventions that assist caregivers to support people with dementia living in the community: a systematic review. Internal Journal Parsons M, Senior H, Kerse $\mathrm{N}$ et al. 2012. Should care managers for older adults be located in primary care? A randomized controlled trial. J Am Geriatr Soc. 201260 : 86-92.

Roman MW, Callen BL. 2008. Screening Instruments for Older Adult Depressive Disorders: Updating the Evidence-Based Toolbox. Issues Ment Health Nurs. 29 : 924-941.

Ross S, Curry N, Goodwind N. 2011. Case management : What it is and how it can best be implemented. Available at: http://www.kingsfund.org.uk/publications/case management.html. Snaith P. 1993. What do depression rating scales measure? The British Journal of Psychiatry. 163 : 293-298. 
Somme D, Trouve H, Dramé M, Gagnon D, Couturier Y, Saint-Jean O. 2012. Analysis of case management programs for patients with dementia: A systematic review. Alzheimer's and Dementia. 8(5) : 426-436. doi: 10.1016/j.jalz.2011.06.004.

Somme D, Trouvé H, Perisset C, Corvol A, Ankri J, Saint-Jean O, de Stampa M. 2014. Adapting the Quebecois method for assessing implementation to the French National Alzheimer Plan 2008-2012: lessons for gerontological services integration. Int J Integr

\section{Care;14:e016}

Sörensen S, Pinquart M, Duberstein P. 2002. How effective are interventions with caregivers? An updated meta-analysis. Gerontologist 42 : 356-372.

Strech D, Synofzik M, Marckmann G. 2008. Systematic reviews of empirical bioethics. J Med Ethics 34 : 472-477.

Surber RW. 1994. Clinical case management: A guide to comprehensive treatment of serious mental illness. Sage focus editions, Vol 167. Thousand Oaks : Calif.

Vedel I, Monette M, Beland F, Monette J, Bergman H. 2011. Ten years of integrated care: backwards and forwards. The case of the province of Québec, Canada. Int J of Integr Care. 2011;11(5). DOI: http://doi.org/10.5334/ijic.574 Verhagen AP, de Vet HC, de Bie RA, Boers M, van A den Brandt P. 2001. The art of quality assessment of RCTs included in systematic reviews. Journal of Clinical Epidemiology. $\mathbf{5 4}$ : $651-54$.

Vickrey BG, Mittman BS, Connor KI, Pearson ML, Della Penna RD, Ganiats TG, et al. 2006. The effect of a disease management intervention on quality and outcomes of dementia care: a randomized, controlled trial. Ann. Intern. Med. $145:$ 713-726.

Wolff JL, Kasper JD. 2006. Caregivers of frail elders: updating a national profile.

Gerontologist 46 : 344-356

Wolff JL, Rand-Giovannetti E, Palmer S, Wegener S, Reider L, Frey K, et al. 2009.

Caregiving and chronic care: the guided care program for families and friends. J. Gerontol. A Biol. Sci. Med. Sci. 64 : 785-791. 
Wolff N. 2000. Using randomized controlled trials to evaluate socially complex services:

problems, challenges and recommendations. J Ment Health Policy Econ 3 : 97-109. 


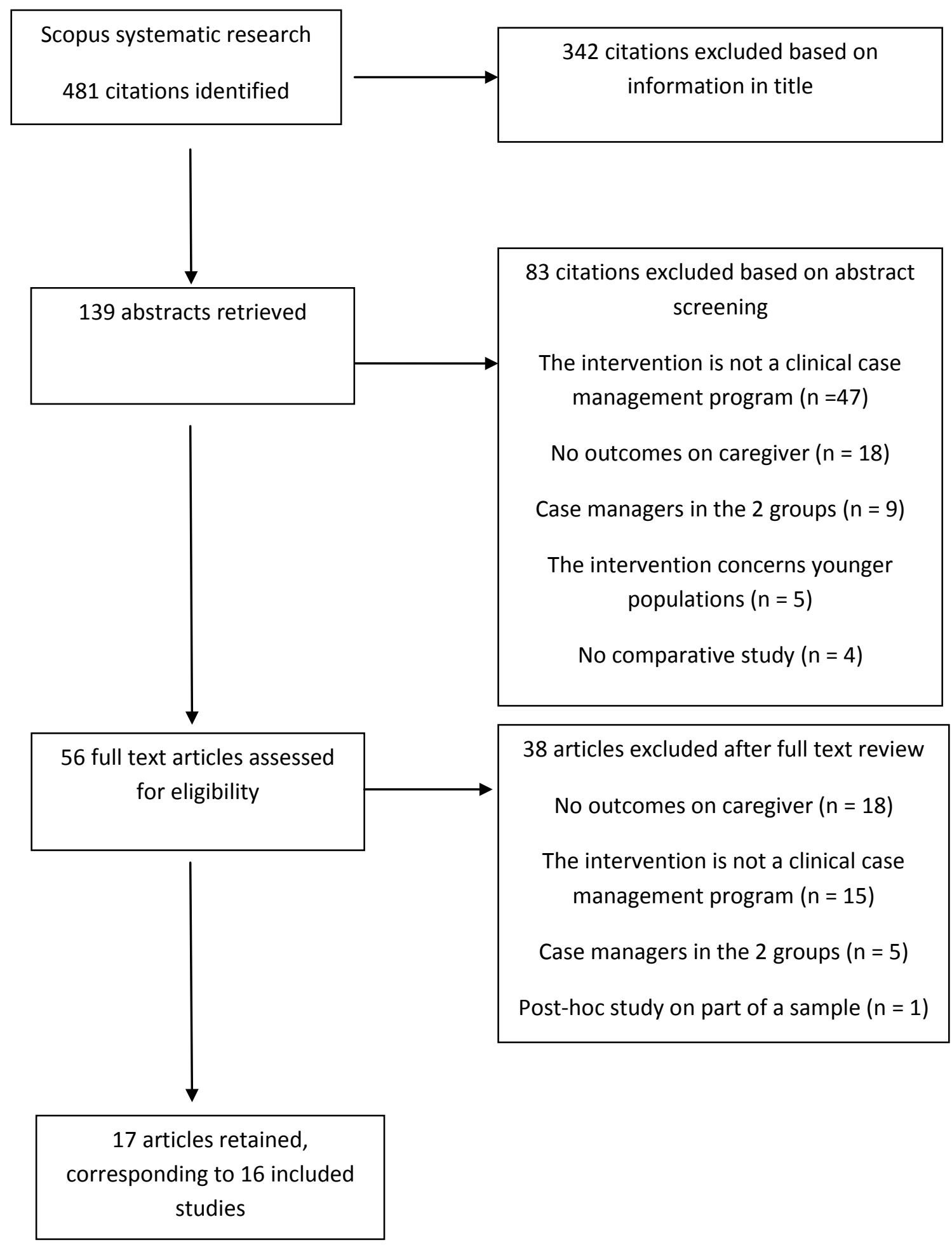

Figure 1: Flowchart of Selection of Studies 


\begin{tabular}{|c|c|c|c|c|c|c|}
\hline $\begin{array}{l}\text { Author, } \\
\text { Year }\end{array}$ & Target Population (patient) & $\begin{array}{l}\text { Patient } \\
\text { Mean } \\
\text { Age }\end{array}$ & $\begin{array}{l}\text { Number of } \\
\text { Caregivers }\end{array}$ & $\begin{array}{l}\text { Caregiver } \\
\text { Mean Age }\end{array}$ & $\begin{array}{c}\% \\
\text { women }\end{array}$ & $\%$ spouse \\
\hline $\begin{array}{l}\text { Newcomer } \\
1999\end{array}$ & $\begin{array}{c}\text { >65 years old, } \\
\text { Diagnosis of dementia }\end{array}$ & 78 & 5307 & 63 & 60 & 50 \\
\hline Challis 2002 & $\begin{array}{l}\text { dementia, significant unmet } \\
\text { needs, risk of } \\
\text { institutionalisation }\end{array}$ & 80 & 86 & 59 & Unknown & 0,2 \\
\hline Leung 2004 & $\begin{array}{c}\text { >60 years old, discharged } \\
\text { from a rehabilitative } \\
\text { hospital }\end{array}$ & 75 & $\begin{array}{l}\text { Unknown } \\
(260 \\
\text { patients })\end{array}$ & Unknown & Unknown & Unknown \\
\hline Béland 2006 & $\begin{array}{l}>64 \text { years old, at least } \\
\text { moderate disability }\end{array}$ & 82 & 1309 & Unknown & Unknown & Unknown \\
\hline Vickrey 2006 & $\begin{array}{c}>65 \text { years old, diagnosis of } \\
\text { dementia }\end{array}$ & 80 & 408 & 66 & 69 & 56 \\
\hline $\begin{array}{c}\text { Callahan } \\
2006\end{array}$ & $\begin{array}{c}>65 \text { years old, diagnosis of } \\
\text { dementia }\end{array}$ & 77,5 & 153 & 61 & 89 & 44 \\
\hline Chien 2008 & $\begin{array}{c}\text { Diagnosis of Alzheimer } \\
\text { disease }\end{array}$ & 68 & 88 & 44 & 64 & 32 \\
\hline $\begin{array}{l}\text { Morales } \\
2008\end{array}$ & $\begin{array}{c}\text { Terminally ill or dependant } \\
\text { patient who require daily } \\
\text { assistance }\end{array}$ & 76 & 205 & 57 & 79 & 25 \\
\hline Wolff 2009 & $\begin{array}{l}>65 \text { years old; high risk of } \\
\text { using health service } \\
\text { resource }\end{array}$ & 78 & 308 & 61 & 70,4 & 48 \\
\hline Hébert 2009 & $\begin{array}{c}>=75 \text {, risk of functional } \\
\text { decline }\end{array}$ & 83 & $1166^{*}$ & Unknown & $75^{*}$ & $35^{*}$ \\
\hline Lam 2010 & $\begin{array}{c}>65 \text { years old, mild } \\
\text { dementia }\end{array}$ & 78 & 102 & Unknown & 75 & 30 \\
\hline Chien 2011 & $\begin{array}{l}\text { Alzheimer disease, mild or } \\
\text { moderate stage }\end{array}$ & 67,8 & 92 & 45 & 66 & 27 \\
\hline Jansen 2011 & $\begin{array}{l}>65+\text { diabetes or } 75 \text { years } \\
\text { old, and dementia }\end{array}$ & 81 & 99 & 62 & 69 & 40 \\
\hline Parsons 2012 & $\begin{array}{l}>65 \text { years old (55 for } \\
\text { Maoris); high } \\
\text { institutionalisation risk }\end{array}$ & 81 & 115 & 67 & 60 & 50 \\
\hline
\end{tabular}


Table 2: Quality assessment of the studies, detailed by outcome

\begin{tabular}{|c|c|c|}
\hline Author, Journal, Year & Internal Validity* & External Validity \\
\hline $\begin{array}{c}\text { Newcomer } \\
\text { Health services Research } \\
1999\end{array}$ & $\begin{array}{c}\text { Non-blinded RCT } \\
\text { High risk of detection bias on the total hours of informal care, with a } \\
\text { possible under-estimation in control group } \\
\text { Implementation bias threw the different sites } \\
\text { Unclear }\end{array}$ & $\begin{array}{l}\text { Recruitment based on voluntary application and little } \\
\text { description of CM tasks } \\
\text { Low }\end{array}$ \\
\hline $\begin{array}{l}\text { Challis } \\
\text { Int J of Geriatric } \\
\text { Psychiatry } 2002\end{array}$ & $\begin{array}{l}\text { Quasi-experimental design } \\
\text { Matched pairs, allowing similar group } \\
\text { Possible detection bias linked with a non-blinded assessment } \\
\text { high risk of performance bias on the outcome "satisfaction with care" } \\
\text { High risk of detection bias on the total hours of informal care } \\
\text { Acceptable }\end{array}$ & $\begin{array}{l}\text { Systematic recruitment; unclear description of the } \\
\text { intervention } \\
\text { Moderate }\end{array}$ \\
\hline $\begin{array}{l}\text { Leung } \\
\text { J of applied gerontology } \\
2004\end{array}$ & $\begin{array}{c}\text { Non-blinded RCT } \\
\text { Assessment blinding unclear } \\
\text { High risk of detection bias on the total hours of informal care } \\
\text { Low concerning the total hours of informal care }\end{array}$ & $\begin{array}{c}\text { No systematic recruitment } \\
\text { No description of the caregiver population } \\
\text { Low }\end{array}$ \\
\hline $\begin{array}{l}\text { Béland } \\
\text { J of Gerontology } \\
2006\end{array}$ & $\begin{array}{l}\text { Non-blinded RCT, } \\
\text { High risk of performance bias on the outcome satisfaction with care } \\
\text { Unclear risk of contamination } \\
\text { Acceptable }\end{array}$ & $\begin{array}{l}\text { No systematic recruitment } \\
\text { Moderate }\end{array}$ \\
\hline $\begin{array}{l}\text { Vickrey } \\
\text { Annals of internal } \\
\text { medicine } \\
2006\end{array}$ & $\begin{array}{c}\text { Non-blinded RCT } \\
\text { No validated tool for caregiver confidence and sense of mastery } \\
\text { Limited implementation } \\
\text { Acceptable }\end{array}$ & High \\
\hline $\begin{array}{l}\text { Callahan } \\
\text { JAMA } 2006\end{array}$ & $\begin{array}{c}\text { Non-blinded RCT } \\
\text { Acceptable }\end{array}$ & $\begin{array}{l}\text { High refusal rate for a complete diagnosis process } \\
\text { Moderate }\end{array}$ \\
\hline $\begin{array}{l}\text { Morales } \\
\text { BMC Health Services } \\
\text { research } 2008\end{array}$ & $\begin{array}{c}\text { Non-blinded quasi-experimental study } \\
\text { Base-line difference in functional capacity } \\
\text { Progressive implementation, implying a contamination bias }\end{array}$ & $\begin{array}{c}\text { Systematic sampling, but unclear description of the } \\
\text { intensity of the intervention } \\
\text { Moderate }\end{array}$ \\
\hline
\end{tabular}


Table 3: Caregiver outcomes with acceptable or unclear internal validity detailed by study.

\begin{tabular}{|c|c|c|c|c|c|}
\hline Publication & Burden & Depression & $\begin{array}{l}\text { Health Related } \\
\text { Quality of life }\end{array}$ & Social support & $\begin{array}{l}\text { Other caregiver } \\
\text { outcomes }\end{array}$ \\
\hline $\begin{array}{l}\text { Newcomer } \\
1999\end{array}$ & $\begin{array}{c}\text { Adapted from Zarit } \\
\text { Carer Burden Interview }\end{array}$ & $\begin{array}{c}\text { Geriatric } \\
\text { depression Scale } \\
\text { (short form) }\end{array}$ & Not assessed & Not assessed & No \\
\hline Challis2002 & $\begin{array}{l}\text { Adapted from the } \\
\text { Social Behaviour } \\
\text { Assessment Schedule } \\
\text { Caregiver strain } \\
\text { (Malaise Scale) }\end{array}$ & Not assessed & Not assessed & Not assessed & No \\
\hline $\begin{array}{l}\text { Béland } \\
2006\end{array}$ & $\begin{array}{l}\text { Zarit Carer Burden } \\
\text { Interview }\end{array}$ & Not assessed & Not assessed & Not assessed & No \\
\hline $\begin{array}{l}\text { Vickrey } \\
2006\end{array}$ & Not assessed & Not assessed & Euroquol 5D & $\begin{array}{c}\text { Medical } \\
\text { Outcome } \\
\text { Study Social } \\
\text { Support }\end{array}$ & $\begin{array}{l}\text { Confidence in } \\
\text { caregiving; } \\
\text { Caregiving } \\
\text { Mastery }\end{array}$ \\
\hline $\begin{array}{l}\text { Callahan } \\
2006\end{array}$ & $\begin{array}{c}\text { Caregiver } \\
\text { Neuropsychiatric } \\
\text { inventory (caregiver } \\
\text { distress) }\end{array}$ & $\begin{array}{l}\text { Patient Health } \\
\text { Questionnaire } 9\end{array}$ & Not assessed & Not assessed & No \\
\hline Chien 2008 & $\begin{array}{l}\text { Family Caregiver } \\
\text { Burden Inventory }\end{array}$ & Not assessed & $\begin{array}{c}\text { World Health } \\
\text { Organization } \\
\text { Quality of Life } \\
\text { Scale }\end{array}$ & $\begin{array}{l}\text { Six-item Social } \\
\text { Support } \\
\text { Questionnaire }\end{array}$ & No \\
\hline Wolff 2009 & $\begin{array}{l}\text { Modified Caregiver } \\
\text { Strain Index }\end{array}$ & $\begin{array}{c}\text { Center for } \\
\text { Epidemiologic } \\
\text { Studies } \\
\text { Depression Scale }\end{array}$ & Not assessed & Not assessed & Productivity loss \\
\hline Lam. 2010 & $\begin{array}{l}\text { Zarit Carer Burden } \\
\text { Interview }\end{array}$ & Not assessed & $\begin{array}{l}\text { General Health } \\
\text { Questionnaire 30; } \\
\text { Personal Well- } \\
\text { Being Index }\end{array}$ & Not assessed & No \\
\hline Chien 2011 & $\begin{array}{l}\text { Family Caregiver } \\
\text { Burden Inventory }\end{array}$ & Not assessed & $\begin{array}{l}\text { World Health } \\
\text { Organization } \\
\text { Quality of Life } \\
\text { Scale }\end{array}$ & $\begin{array}{l}\text { Six-item Social } \\
\text { Support } \\
\text { Questionnaire }\end{array}$ & No \\
\hline $\begin{array}{l}\text { Jansen. } \\
2011\end{array}$ & $\begin{array}{l}\text { Self Perceived Pressure } \\
\text { by Informal Carer }\end{array}$ & $\begin{array}{c}\text { Center for } \\
\text { Epidemiologic } \\
\text { Studies } \\
\text { Depression Scale }\end{array}$ & $\begin{array}{l}\text { Medical Outcome } \\
\text { Study } 36 \text { items } \\
\text { Short form }\end{array}$ & Not assessed & $\begin{array}{c}\text { Caregiver sense of } \\
\text { competence (Sense } \\
\text { of Competence } \\
\text { Questionnaire) }\end{array}$ \\
\hline $\begin{array}{c}\text { Parsons } \\
2012\end{array}$ & $\begin{array}{l}\text { Caregiver Reaction } \\
\text { Assessment }\end{array}$ & Not assessed & $\begin{array}{l}\text { Medical Outcome } \\
\text { Study } 36 \text { items } \\
\text { Short form }\end{array}$ & Not assessed & No \\
\hline $\begin{array}{l}\text { MacNeil } \\
2015\end{array}$ & CarerQOL & Not assesssed & $\begin{array}{c}\text { Euroquol 5D } \\
\text { General Health } \\
\text { Questionnaire } 12\end{array}$ & Not assessed & $\begin{array}{l}\text { Pearlin Mastery } \\
\text { Scale } \\
\text { Short sense of } \\
\text { competence scale } \\
\text { Loneliness scale }\end{array}$ \\
\hline
\end{tabular}


Table 4: Program characteristics and statistically significant outcomes for caregivers and patients.

\begin{tabular}{|c|c|c|c|c|c|c|}
\hline & $\begin{array}{l}\text { Patient } \\
\text { Profile }\end{array}$ & $\begin{array}{l}\text { Duration of } \\
\text { the Case } \\
\text { Management } \\
\text { Program (in } \\
\text { months) }\end{array}$ & Intensity & Integration & $\begin{array}{l}\text { Positive } \\
\text { Outcomes } \\
\text { Concerning } \\
\text { Caregivers }\end{array}$ & $\begin{array}{l}\text { Positive Outcomes } \\
\text { Concerning Patients }\end{array}$ \\
\hline Challis 2002 & dementia & 12 & high & high & $\begin{array}{l}\text { lower } \\
\text { burden }\end{array}$ & $\begin{array}{c}\text { less } \\
\text { institutionalisation } \\
\text { improvement in } \\
\text { social contacts, need } \\
\text { reduction, level of } \\
\text { risk reduction }\end{array}$ \\
\hline $\begin{array}{l}\text { Callahan } \\
2006\end{array}$ & dementia & 12 & high & low & $\begin{array}{l}\text { lower } \\
\text { burden }\end{array}$ & $\begin{array}{c}\text { lower Neuro- } \\
\text { psychiatric } \\
\text { inventory } \\
\end{array}$ \\
\hline Chien 2008 & dementia & 6 & high & moderate & $\begin{array}{c}\text { lower } \\
\text { burden, } \\
\text { better QoL }\end{array}$ & $\begin{array}{c}\text { less } \\
\text { institutionalisation; } \\
\text { decrease of } \\
\text { symptom severity }\end{array}$ \\
\hline $\begin{array}{l}\text { Chien } \\
2011\end{array}$ & dementia & 6 & high & moderate & $\begin{array}{c}\text { lower } \\
\text { burden, } \\
\text { better QoL }\end{array}$ & $\begin{array}{c}\text { less } \\
\text { institutionalisation }\end{array}$ \\
\hline $\begin{array}{l}\text { MacNeil2015 } \\
\text { Intensive CM }\end{array}$ & dementia & 24 & Unclear & High & better QoL & no \\
\hline $\begin{array}{l}\text { Vickrey } \\
2006\end{array}$ & dementia & 18 & moderate & moderate & $\begin{array}{l}\text { better social } \\
\text { support and } \\
\text { confidence } \\
\text { in } \\
\text { caregiving }\end{array}$ & $\begin{array}{l}\text { higher care quality; } \\
\text { higher quality of } \\
\text { life; } \\
\text { better social } \\
\text { support; } \\
\text { fewer unmet needs }\end{array}$ \\
\hline $\begin{array}{c}\text { Newcomer } \\
1999\end{array}$ & dementia & 36 & unclear & low & no & fewer unmet needs \\
\hline $\begin{array}{l}\text { MacNeil2015 } \\
\text { Linkage } \\
\text { model }\end{array}$ & dementia & 24 & Unclear & low & no & no \\
\hline $\begin{array}{l}\text { Leung } \\
2004\end{array}$ & elderly & 6 & moderate & high & no & less hospitalisation \\
\hline $\begin{array}{l}\text { Béland } \\
2006\end{array}$ & frail elderly & 22 & high & high & no & less hospitalisation \\
\hline Wolff 2009 & frail elderly & 18 & moderate & moderate & no & $\begin{array}{l}\text { Reduction in the use } \\
\text { of home health care }\end{array}$ \\
\hline Lam 2010 & $\begin{array}{c}\text { mild } \\
\text { dementia }\end{array}$ & 4 & moderate & moderate & no & no positive results \\
\hline Jansen 2011 & $\begin{array}{c}\text { mild } \\
\text { dementia }\end{array}$ & 12 & moderate & moderate & no & $\begin{array}{c}\text { No effect on quality } \\
\text { of life }\end{array}$ \\
\hline Parsons 2012 & frail elderly & 24 & unclear & high & no & $\begin{array}{c}\text { fewer residential } \\
\text { placement }+ \text { death }\end{array}$ \\
\hline
\end{tabular}

Studies with statistically significant outcomes for caregivers are in the upper part of the table.

QoL: Health related quality of life 
The instrument used in each study is listed. Statistically significant results are in bold. 


\begin{tabular}{|c|c|c|}
\hline & $\begin{array}{l}\text { High risk of detection bias, as assessment is made by the case managers in } \\
\text { the intervention group } \\
\text { Low }\end{array}$ & \\
\hline $\begin{array}{c}\text { Wolff } \\
\text { Gerontologist } 2009\end{array}$ & $\begin{array}{c}\text { Non-blinded RCT } \\
\text { High risk of performance bias for satisfaction with care } \\
\text { Possible detection bias for depression } \\
\text { Limited implementation } \\
\text { Acceptable }\end{array}$ & High \\
\hline $\begin{array}{l}\text { Hébert } \\
\text { J of Gerontology } \\
2009\end{array}$ & $\begin{array}{c}\text { Non-blinded quasi-experimental study } \\
\text { Baseline difference in age (older in experimental group) and caregiver } \\
\text { burden (lower in experimental group) } \\
\text { Unclear report on which analysis were pre specified } \\
\text { Low }\end{array}$ & $\begin{array}{l}\text { Missing data on caregiver } \\
\text { Moderate }\end{array}$ \\
\hline $\begin{array}{l}\text { Chien } \\
\text { Psychiatric services } \\
2010 \\
\end{array}$ & $\begin{array}{l}\text { Non-blinded RCT } \\
\text { Unclear contamination, implementation and reporting bias } \\
\text { unclear }\end{array}$ & High \\
\hline $\begin{array}{l}\text { Lam } \\
\text { Int J of Geriatric } \\
\text { Psychiatry } \\
2010\end{array}$ & $\begin{array}{l}\text { Non-blinded RCT } \\
\text { Unclear contamination and implementation bias } \\
\text { Acceptable }\end{array}$ & $\begin{array}{l}\text { Only one CM, recruitment in a memory clinic } \\
\text { Low }\end{array}$ \\
\hline $\begin{array}{l}\text { Chien } \\
\text { J of Advanced Nursing } \\
2011 \\
\end{array}$ & $\begin{array}{c}\text { Non-blinded RCT } \\
\text { unclear implementation and contamination bias } \\
\text { Acceptable }\end{array}$ & $\begin{array}{l}\text { Non-systematic recruitment in a dementia resource } \\
\text { centre; young patients (68) } \\
\text { Low }\end{array}$ \\
\hline $\begin{array}{c}\text { Jansen } \\
\text { Int J of Nursing Studies } \\
2011\end{array}$ & $\begin{array}{c}\text { Non-blinded RCT } \\
\text { High risk of performance bias for satisfaction with care } \\
\text { Tool validity not sufficient for the caregiver sense of competence } \\
\text { Possible detection bias for depression } \\
\text { Reporting bias (day of hospitalisation) } \\
\text { Limited implementation } \\
\text { Acceptable }\end{array}$ & High \\
\hline $\begin{array}{l}\text { Parsons } \\
\text { JAGS } \\
2012(\end{array}$ & $\begin{array}{l}\text { Non-blinded RCT } \\
\text { Non-blinded Assessment } \\
\text { Unclear implementation } \\
\text { Acceptable }\end{array}$ & $\begin{array}{l}\text { Systematic recruitment, but insufficient description of } \\
\text { the intervention } \\
\text { Moderate }\end{array}$ \\
\hline Janse & Non blinded quasi-experimental study & \\
\hline
\end{tabular}




\begin{tabular}{|c|c|c|}
\hline BMC geriatrics 2014 & $\begin{array}{c}\text { Selection bias, with baseline differences in patients (gender and home } \\
\text { living) } \\
\text { Attrition bias, with } 40 \% \text { of the caregiver loss to follow up } \\
\text { Low }\end{array}$ & $\begin{array}{l}\text { No systematic recruitment } \\
\text { Well implemented intervention } \\
\text { Moderate }\end{array}$ \\
\hline $\begin{array}{c}\text { MacNeil } \\
\text { JAMDA } 2015\end{array}$ & $\begin{array}{l}\text { Selection bias corrected by appropriated statistical analysis (propensity } \\
\text { score) } \\
\text { Possible contamination bias } \\
\text { Low }\end{array}$ & $\begin{array}{l}\text { High refusal rate } \\
\text { Moderate }\end{array}$ \\
\hline
\end{tabular}

RCT: randomized controlled trial

CM: case manager 


\begin{tabular}{|c|c|c|c|c|c|c|}
\hline Janse 2014 & $\begin{array}{c}\text { 75 years old and frail } \\
\text { (Groningen frailty } \\
\text { indicator) }\end{array}$ & 82 & 159 & 63 & 73 & 32 \\
\hline $\begin{array}{c}\text { Macneil } \\
2015\end{array}$ & diagnosis of dementia & 80 & 521 & 65 & 67 & 52 \\
\hline
\end{tabular}

Table 1: Main characteristics of participants, patients and caregivers, in the 16 identified studies.

*extrapolation from data concerning only the first recruitment wave 